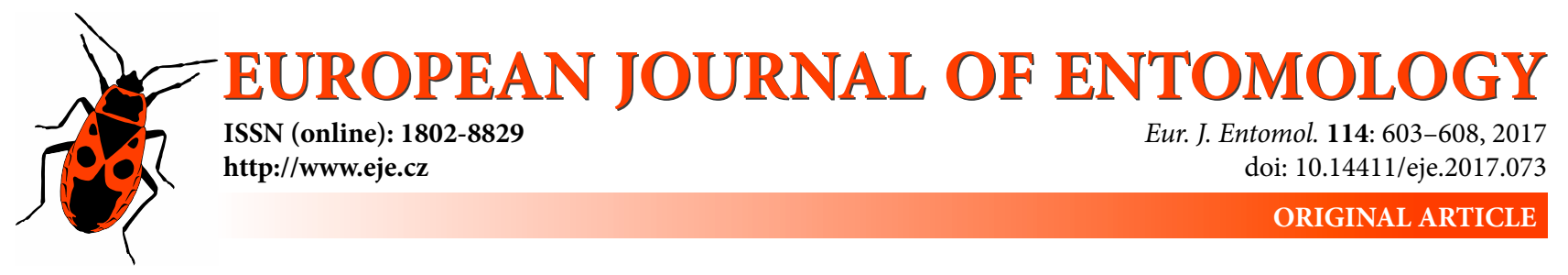

\title{
Suitability of Bemisia tabaci (Hemiptera: Aleyrodidae) biotype-B and Myzus persicae (Hemiptera: Aphididae) as prey for the ladybird beetle, Serangium japonicum (Coleoptera: Coccinellidae)
}

\author{
Mı TIAN, Yuling WEI, Shize ZHANG* and TongXIAN LIU \\ Key Laboratory of Integrated Pest Management on the Loess Plateaus of Ministry of Agriculture, Northwest A\&F University, \\ Yangling, Shaanxi 712100, China; e-mails: 526244663@qq.com, 820604614@qq.com, shzzhang@nwafu.edu.cn, \\ txliu@nwsuaf.edu.cn
} Key words. Hemiptera, Aleyrodidae, Bemisia tabaci, cotton whitefly, Aphididae, Myzus persicae, green peach aphid,
Coleoptera, Coccinellidae, Serangium japonicum, prey suitability, biological control

\begin{abstract}
The ladybird, Serangium japonicum (Coleoptera: Coccinellidae), is one of the most important predators of whiteflies in China, however, the suitability of different kinds of prey and nutritional requirements of this predator are poorly studied. The objectives of the present study were to investigate the pre-imaginal development, percentage survival of immatures, adult longevity and fecundity of $S$. japonicum when reared on two different species of prey, mixed ages of the cotton whitefly Bemisia tabaci Gennadius (Hemiptera: Aleyrodidae) biotype-B (i.e., eggs and nymphs) and green peach aphid Myzus persicae (Sulzer) (Hemiptera: Aphididae) in order to quantify their relative suitability as prey under laboratory conditions of $25 \pm 1{ }^{\circ} \mathrm{C}, 50 \pm 10 \% \mathrm{RH}$ and a photoperiod of $16 \mathrm{~L}: 8 \mathrm{D}$. The results of this study indicate that the total developmental period (from egg to adult) was shorter when they were fed on $B$. tabaci $(18.29 \pm 0.13$ days) than on $M$. persicae (19.85 \pm 0.22 days). The percentage survival of the immatures, growth index, development rate, adult fresh weight, fecundity and percentage of eggs hatching were higher and the pre-oviposition period was significantly shorter when $S$. japonicum were fed on $B$. tabaci than on $M$. persicae. In contrast, there was no significant difference in their longevity and oviposition period when fed on $B$. tabaci and M. persicae. The results indicate that as a diet for $S$. japonicum M. persicae is inferior to B. tabaci. This is the first record of $S$. japonicum being able to complete its development feeding exclusively on $M$. persicae. Since B. tabaci and $M$. persicae often simultaneously occur in vegetable fields, these results indicate that it is likely that $S$. japonicum could be utilized to control mixed populations of aphids and whiteflies, and furthers our understanding of ladybird population dynamics in the field in relation to the availability of different species of prey.
\end{abstract}

\section{INTRODUCTION}

The cotton whitefly, Bemisia tabaci (Gennadius) (Hemiptera: Aleyrodidae), occurs worldwide in tropical and subtropical climates as well as in protected agricultural systems in temperate regions. It is an important pest of more than 600 species of plants of numerous field and vegetable crops in many parts of the world (Naranjo et al., 2010). Whiteflies cause serious damage by feeding, producing honeydew and the resultant sooty mould, and disease transmission (Stansly \& Natwick, 2010). Although known as a sporadic pest of cotton in China for many years, Bemisia tabaci Biotype-B did not become an important pest in northern China until 2000 (Wu et al., 2002), and is now widely distributed across China (Hu et al., 2011). Many attempts have been made to control B. tabaci. Because of its high reproductive rate, many generations per year and ability to rapidly develop resistance to insecticides, whiteflies are difficult to control using conventional means (Castle et al., 2010). Thus, biological control becomes the primary method for suppressing whitefly populations in agroecosystems (Arno et al., 2010).

The green peach aphid, Myzus persicae (Sulzer) (Hemiptera: Aphididae), is a highly polyphagous insect pest, which feeds on more than 400 species of plants belonging to over 50 families including agricultural crops (e.g., potato, sugar beet and tobacco), horticultural crops (e.g., plants of Brassicaceae, Solanaceae and Cucurbitaceae) and stone fruit (e.g., peach, apricot and cherry) around the world. It causes enormous economic losses because it reduces crop yields by sucking plant sap, transmits over 100 plant viruses and secretes honeydew (Blackman \& Eastop, 2000; Kim et al., 2005). Currently, control of M. persicae is mostly based on insecticides, and high levels of insecticide resistance are recorded in many parts of the world (Li et al.,

\footnotetext{
* Corresponding author; e-mail: shzzhang@nwafu.edu.cn
} 
2016). Effective and environmentally sound management of this whitefly and aphid is needed, and biological control using natural enemies is an attractive option.

The ladybird, Serangium japonicum Chapin (Coleoptera: Coccinellidae), is an important predator of whiteflies and scale insects (Ren et al., 2009). It occurs in China and Japan, where $S$. japonicum is potentially a good biological control agent of $B$. tabaci in various crop systems in China, especially vegetables and cotton (Ren et al., 2001). Serangium japonicum larvae and adults feed on the immature stages of $B$. tabaci and can effectively suppress its population growth ( $\mathrm{Li}$ et al., 2015). However, the nutritional ecology, prey preference and food requirements for development and reproduction of $S$. japonicum are not well studied.

Food quality is one of the most important factors influencing the vigour of predators because not all species of prey are equally suitable as food. These influences range from slight effects such as longer developmental times, or a decrease in percentage larval survival to dramatic effects such as toxicity of certain species of prey resulting in high mortality (Obrycki \& Kring, 1998). Given that there may be a number of alternative prey available to some predatory insects in an agroecosystem, preference for and the suitability of prey for development are important in determining the potential of predators as biological control agents of a specific pest, which may determine the success or failure of predators in biological control systems (Thompson, 1999). Furthermore, many predatory insects are opportunistic predators in the field and feed on a wide range of species of prey and plant products, but this behaviour may not clearly indicate prey suitability and predator nutritional requirements (Strohmeyer et al., 1998).

In developing an effective IPM program for controlling B. tabaci it would be advantageous to maximize the effectiveness of the chosen natural enemy. During a preliminary investigation, we found that $S$. japonicum frequently fed not only whiteflies, but also on the green peach aphid in vegetable fields in north western China. This prompted us to speculate that $S$. japonicum could prey on both whiteflies and aphids. Since $S$. japonicum is known as a promising predator of whiteflies, we therefore hypothesized that different species of prey might vary in their suitability as prey for $S$. japonicum. The objective of this study was to determine whether $B$. tabaci and $M$. persicae were equally suitable for the development, survival, longevity and fecundity of $S$. japonicum.

\section{MATERIALS AND METHODS}

\subsection{Insects}

Serangium japonicum adults were originally collected from the experimental farm of the Northwest A\&F University (Yangling, Shaanxi, China; $34^{\circ} 17^{\prime} 09.35^{\prime \prime} \mathrm{N}$ and $\left.108^{\circ} 04^{\prime} 17.12^{\prime \prime} \mathrm{E}\right)$. They were maintained in the laboratory on potted cabbage (Brassica oleracea L.) infested with immature $B$. tabaci. All cultures were kept in nylon mesh covered cages $(60 \times 60 \times 60 \mathrm{~cm})$ in a greenhouse maintained at $20-30^{\circ} \mathrm{C}$ under a natural light regime.

Myzus persicae used as prey for the ladybird was cultured on sweet pepper (Capsicum annuum L.) plants in the laboratory for
3 years. Bemisia tabaci B biotype was collected from tomato (Solanum lycopersicum L.) in a greenhouse in Yangling, Shaanxi, China $\left(34^{\circ} 17^{\prime} 37.01^{\prime \prime} \mathrm{N}\right.$ and $\left.108^{\circ} 01^{\prime} 03.34^{\prime \prime} \mathrm{E}\right)$. They were reared on cabbage in mesh covered cages $(60 \times 60 \times 60 \mathrm{~cm})$ in the same greenhouse. The whiteflies were identified as $B$. tabaci B-biotype by RAPD-PCR using the mitochondrial COI gene (Wu et al., 2002). To produced mixed ages of $B$. tabaci (eggs and nymphs), cabbage plants were exposed to $B$. tabaci adults in the stock culture cages for $48 \mathrm{~h}$, and then incubated in growth chambers under the same conditions as the ladybirds and aphids. To avoid food adaptation, populations of the adult beetles were established in the same greenhouse and supplied with a mixture of $B$. tabaci and $M$. persicae on their respective host plants in mesh covered cages $(60 \times 60 \times 60 \mathrm{~cm})$ for several generations before they were used in this study.

\subsection{Pre-adult development and immature survival}

Effect of prey species on the pre-adult development and immature survival of $S$. japonicum was evaluated. Leaves with beetle eggs ( $<2$ h old, about eighty eggs) were excised from plants and placed in two plastic boxes (length $\times$ width $\times$ depth $=8 \times 6 \times 3 \mathrm{~cm}$, covered with fine muslin cloth for ventilation) until they hatched. A piece of filter paper was placed at the bottom of the boxes, and a few drops of water were added as needed to maintain humidity. The boxes with the insects were kept in a climatic chamber $\left(25 \pm 1{ }^{\circ} \mathrm{C}, 50 \pm 10 \% \mathrm{RH}\right.$ under a photoperiod of $\left.16 \mathrm{~L}: 8 \mathrm{D}\right)$. The $S$. japonicum eggs were inspected carefully every $6 \mathrm{~h}$ and the number that hatched were recorded. Newly hatched first instars of $S$. japonicum $(<6 \mathrm{~h}$ old) were individually transferred to Petri dishes $(9.0 \mathrm{~cm}$ in diameter and $3.0 \mathrm{~cm}$ in height) using a soft camel hair brush and placed in the close vicinity of the prey. A piece of filter paper was placed at the bottom of the Petri dish and a few drops of water were added as needed to maintain humidity. Our preliminary test showed that the first instar larvae of $S$. japonicum did not feed on the adult aphids, so only first instar nymphs of $M$. persicae (about 20-30) were fed to first instar larvae of S. japonicum. A mixed age group of aphids (about 60-80) were selected for testing after the first instar ladybirds moulted to the second instar. The sweet pepper leaf with aphids was replaced every $12 \mathrm{~h}$ to avoid microbial contamination.

To provide whitefly prey, a cabbage leaf infested with mixed ages of $B$. tabaci was put into a Petri dish $(9.0 \mathrm{~cm}$ in diameter and $3.0 \mathrm{~cm}$ in height). One first instar larva of $S$. japonicum ( $<6 \mathrm{~h}$ old) was added to the arena. Afterwards, each $S$. japonicum larva was transferred daily to a new arena containing fresh prey.

All experiments were conducted in climatic chambers at $25 \pm 1{ }^{\circ} \mathrm{C}, 50 \pm 10 \% \mathrm{RH}$ under a photoperiod of $16 \mathrm{~L}: 8 \mathrm{D}$. Forty newly hatched $S$. japonicum larvae $(<6 \mathrm{~h}$ old) were reared on each category of prey. $S$. japonicum larvae were checked for moulting or death every $6 \mathrm{~h}$. The duration of development of each immature stage of $S$. japonicum was recorded and the initial body mass of newly-emerged adults was determined by weighing them individually on an electronic balance (Mettler-Toledo XS64, Greifensee, Switzerland) with a precision of $0.1 \mathrm{mg}$.

Percentage immature survival, adult emergence and development rate (1/developmental period) were recorded using the following formulae, and the growth index is that proposed by Dubey et al. (1981). Survival was calculated as: Percentage survival $(\%)=$ Number surviving in an assessed instar/Number surviving in the previous instar $\times 100$. Growth index was calculated as: Growth index $=$ Percentage pupation $/$ Developmental time of larvae $\times 100$. Percentage pupation $(\%)=$ Number of pupae $/$ Number of fourth instar larvae $\times 100$. Percentage adult emergence $(\%)=$ Number of adults emerged / Number of pupae $\times 100$. Percentage 
survival to the adult stage $(\%)=$ Number of adults that emerged $/$ Initial number of first instar larvae $\times 100$.

\subsection{Longevity and reproductive performance}

To evaluate the longevity and reproductive performance of $S$ japonicum, newly emerged adults were sexed and paired. A total of fifteen randomly selected pairs were used. Each pair was kept in a Petri dish $(9.0 \mathrm{~cm}$ in diameter and $3.0 \mathrm{~cm}$ in height $)$. A piece of filter paper was placed at the bottom of the Petri dish and a few drops of water added as needed to maintain humidity. Petri dishes were placed in climatic chambers with the same settings as above. Fresh leaf disks with $B$. tabaci or M. persicae were provided daily as a source of food. Each couple was observed daily to record longevity, pre-oviposition period, oviposition period and fecundity (number of eggs laid) until all beetles died.

\subsection{Data analysis}

Duration of development of immature stages, developmental rate, longevity, preoviposition period, oviposition period, fecundity and adult body weight of $S$. japonicum were analyzed using one-way analysis of variance (ANOVA); percentage survival was analyzed using the survival analysis (Log Rank test). The experimental data were analyzed using the statistical package SPSS 10.0 (2000; Chicago, IL, USA).

\section{RESULTS}

\subsection{Development and survival of immature S. japonicum}

The duration of development of the eggs, third instar and fourth instar larvae of $S$. japonicum were shorter when they fed on B. tabaci than on M. persicae (Table 1). When larvae of $S$. japonicum fed on B. tabaci, the developmental time of the pupa increased by $17.1 \%$ compared to those fed on $M$. persicae (Table 1). The total developmental period (from egg to adult) was significantly shorter when they fed on $B$. tabaci than on $M$. persicae (Table 1). The body mass of newly emerged adults differed significantly after feeding on $M$. persicae compared to B. tabaci, and was higher when fed on B. tabaci (Table 1). The percentage survival of first, second, third and fourth instar larvae and the pupal stage did not vary significantly between $S$. japonicum larvae fed on $B$. tabaci and $M$. persicae $\left(\chi^{2}=1.459, P=\right.$ 0.227 ) (Fig. 1). The percentage of larvae reaching the adult stage was much higher $(95 \%)$ when fed on B. tabaci than on $M$. persicae $(67.5 \%)\left(\chi_{0.05}^{2}=9.928, P<0.005\right)$.

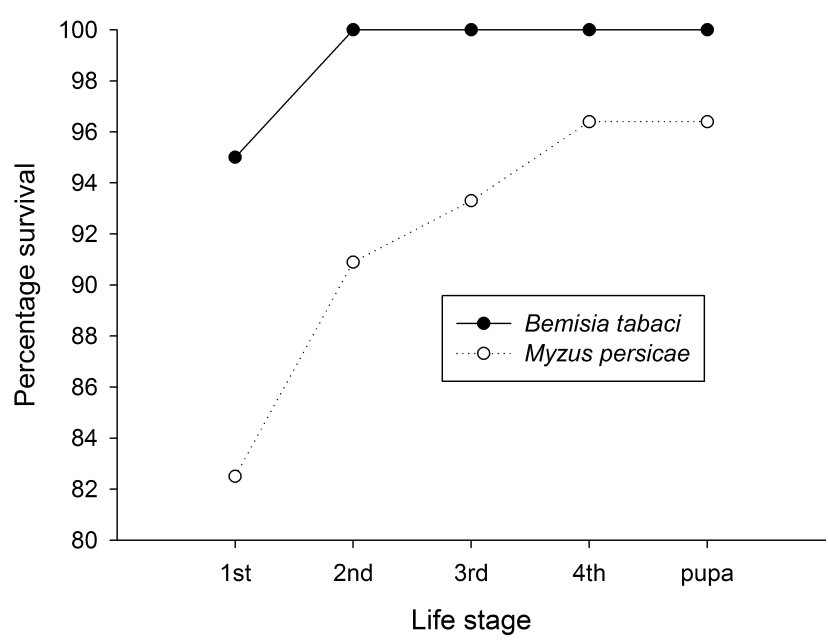

Fig. 1. Percentage survival of the immature stages of Serangium japonicum fed on Myzus persicae and Bemisia tabaci.

\subsection{Reproductive potential and longevity on different species of prey}

The growth index of $S$. japonicum was higher when fed on B. tabaci than on M. persicae (Table 2). The developmental rate of the ladybirds was similar on the two species of prey (Table 2). When S. japonicum fed on B. tabaci, the preoviposition period markedly decreased by $55.5 \%$ compared to when fed on $M$. persicae (Table 2), but the percentage of eggs that hatched significantly increased (Table 2). The oviposition period and longevity did not differ significantly when $S$. japonicum was fed on B. tabaci or $M$. persicae, although they were shorter when the ladybird fed on B. tabaci (Table 2). The fecundity of the ladybird adults fed $B$. tabaci was significantly increased by $59.3 \%$ compared to on $M$. persicae (Table 2).

Over most of the oviposition period, daily fecundity of $S$. japonicum fed on B. tabaci was higher than on M. persicae (Fig. 2). Daily fecundity of the ladybird was more than 10 eggs per female in the periods 14 to 19 days, 27 to 29 days and 33 to 36 days after the onset of oviposition. When fed on $B$. tabaci a maximum daily fecundity of 46 eggs was recorded on day 17. Mean total fecundity per female was 294.5 eggs when fed on B. tabaci (Table 2) and a single female laid 489 eggs. When S. japonicum fed on M. persicae, the daily fecundity was a relatively constant (around 5 eggs) for 53 days (Fig. 2) and the maximum daily fecundity recorded was 17 eggs on day 42 . Mean fecundity per female was 184.9 eggs and a single female laid 372 eggs.

Table 1. Duration of development (days) of the different immature stages and adult body mass of Serangium japonicum fed on Myzus persicae and Bemisia tabaci.

\begin{tabular}{|c|c|c|c|c|c|}
\hline \multirow{2}{*}{ Stage } & \multicolumn{2}{|c|}{ Duration of development, days \pm SE } & \multirow{2}{*}{ df } & \multirow{2}{*}{$\mathrm{F}$} & \multirow{2}{*}{$P$} \\
\hline & Bemisia tabaci & Myzus persicae & & & \\
\hline Egg & $3.83 \pm 0.01$ & $4.94 \pm 0.04$ & 1,79 & 652.552 & 0.0001 \\
\hline First instar & $2.16 \pm 0.06$ & $2.33 \pm 0.09$ & 1,67 & 0.935 & 0.337 \\
\hline Second instar & $1.77 \pm 0.03$ & $1.93 \pm 0.12$ & 1,64 & 1.546 & 0.218 \\
\hline Third instar & $1.52 \pm 0.06$ & $2.08 \pm 0.04$ & 1,62 & 59.652 & 0.0001 \\
\hline Fourth instar & $4.18 \pm 0.04$ & $4.43 \pm 0.13$ & 1,62 & 4.714 & 0.034 \\
\hline Pupa & $4.83 \pm 0.06$ & $4.14 \pm 0.08$ & 1,62 & 60.053 & 0.0001 \\
\hline Egg-adult & $18.29 \pm 0.13$ & $19.85 \pm 0.22$ & 1,61 & 33.030 & 0.0001 \\
\hline Adult body weight (mg) & $1.53 \pm 0.02$ & $1.43 \pm 0.03$ & 1,61 & 6.065 & 0.017 \\
\hline
\end{tabular}




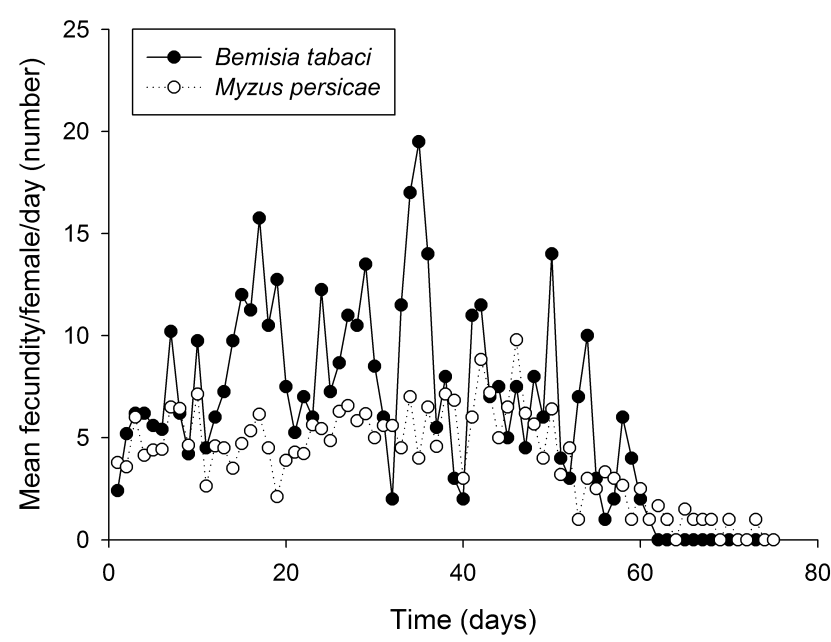

Fig. 2. Mean fecundity of Serangium japonicum fed on Bemisia tabaci and Myzus persicae. Note: for clarity the error bars of each data point were not included.

\section{DISCUSSION}

The quality of prey affect the development, survival and reproduction of coccinellids (Thompson, 1999). Hodek (1996) categorized prey into essential, alternative and rejected based on their effect on the developmental rate, survival and reproductive capacity of coccinellid predators. Our study indicates that both $B$. tabaci and $M$. persicae are suitable prey for the development of $S$. japonicum, but the percentage survival of immatures of $S$. japonicum fed on $M$. persicae was relatively low (67.5\%). Zhang et al. (2012) document Acyrthosiphon pisum as a suitable prey for Propylea japonica, however, the larvae of this ladybird fed on A. pisum had a lower percentage survival than those fed on other species of aphid. Osman \& Selman (1993) also report that $M$. persicae, A. pisum and Aphis fabae are suitable prey for the lacewing, Chrysoperla carnea, but those fed on $A$. fabae suffered a higher juvenile mortality than those fed on $M$. persicae. The enhanced performance of predatory coccinellid larvae on certain prey may be related to their higher protein levels or higher palatability (Omkar \& Srivastava, 2003).

There may be different levels of suitability of individual essential prey. In the present study the different species of prey did not significantly affect the percentage survival of the coccinellid larvae, but each larval instar survived less well when fed on $M$. persicae than on B. tabaci. However, significantly fewer of the $S$. japonicum fed on $M$. persicae survived to the adult stage and were lighter in weight, had a lower fecundity and a lower percentage of their eggs hatched. Osman \& Selman (1993) report that although $A$. fabae is a suitable prey for the lacewing $C$. carnea it results in this predator producing smaller cocoons and having a lower fecundity. The fertility of Propylea japonica reared on Ephestia kuehniella eggs is significantly lower than when reared on $A$. pisum, though both are regarded as essential prey (Hamasaki \& Matsui, 2006). These studies reveal that suppression of growth and developmental rate of larvae is likely to affect the size and maturation of adults, which in turn may result in reduced reproductive success or survival. More interestingly, we found that when $S$. japonicum fed on $M$. persicae, the preoviposition period was significantly prolonged but the oviposition period and longevity were not significantly different. When adults of $S$. japonicum are fed on the less nutritious food (i.e., $M$. persicae) it may affect the development of their testes and sperm and/or oocytes and ovarian development that could result in the extension in pre-oviposition period. On the other hand, these females could allocate more resources to longevity at the cost of a reduction in reproduction so as to maintain population development. Further investigations are needed to elucidate the physiological mechanisms that underlie the effect of feeding on less nutritious prey on the subsequent fitness and life history characteristics of $S$. japonicum.

$S$. japonicum has considerable potential as a biocontrol agent of B. tabaci in China (Lin et al., 2008). However, the general biology of this ladybird is not well studied. To date, most information on $S$. japonicum is limited to its compatibility with entomopathogenic fungi (Fatiha et al., 2008; $\mathrm{Hu}$ et al., 2009) or insecticides (He et al., 2012; Li et al., 2015; Yao et al., 2015). Only two studies assess the development, survival and reproduction of this ladybird when fed on B. tabaci on different host plants, which resulted in the longevity and fecundity of the females differing significantly (Jing et al., 2003; Yao et al., 2011). In general, host plants on which prey feed affect the nutrition of the prey, and in turn, affect the development and survival of the predator (Giles et al., 2002). Therefore, it is necessary to evaluate the effects of different species and cultivars of host plants on the development, survival and reproduction of $S$. japonicum in order to improve the efficiency of the control of whiteflies.

Currently more than 40 species of coccinellid are described as predators of $B$. tabaci; however, recent work has only focused on Serangium parcesetosum and Delphastus catalinae. Detailed evaluation and utilization of most ladybeetles is lacking (Arno et al., 2010). We think this is due to the poor knowledge of their food ecology

Table 2. Growth and reproductive parameters of Serangium japonicum fed on Myzus persicae and Bemisia tabaci.

\begin{tabular}{lccccc}
\hline Parameters & Bemisia tabaci & Myzus persicae & df & F & $P$ \\
\hline Growth index & 10.31 & 9.01 & & & \\
Developmental rate (day ${ }^{-1}$ ) & $0.069 \pm 0.001$ & $0.067 \pm 0.001$ & 1,61 & 2.056 & 0.157 \\
Preoviposition period (days) & $9.3 \pm 0.3$ & $20.9 \pm 1.2$ & 1,29 & 84.599 & 0.001 \\
Oviposition period (days) & $61.4 \pm 5.2$ & $71.2 \pm 2.5$ & 1,29 & 2.944 & 0.097 \\
Longevity (days) & $79.8 \pm 3.9$ & $89.3 \pm 3.8$ & 1,59 & 3.078 & 0.085 \\
Fecundity & $294.5 \pm 38.5$ & $184.9 \pm 26.5$ & 1,29 & 5.510 & 0.026 \\
Percentage of eggs that hatched (\%) & $96.7 \pm 0.8$ & $72.9 \pm 3.1$ & 1,29 & 59.294 & 0.001 \\
\hline
\end{tabular}


and behaviour. In the present study, we firstly found that $S$. japonicum can complete its development and growth when fed exclusively on $M$. persicae, although this aphid is not the best quality prey for this predator. In northern China, both $B$. tabaci and $M$. persicae often coexist in the field and on greenhouse grown vegetables, though their relative abundance varies over time (Zhang et al., 2007). Since $S$. japonicum is an effective predator of B. tabaci (Ren et al., 2001), the possibility of utilizing a single natural enemy to control mixed populations of aphids and whiteflies may reduce costs when $S$.japonicum is used for whitefly control in greenhouses. In addition, our results demonstrate that $S$. japonicum can complete its life history when only feeding on $M$. persicae. Therefore, this ladybeetle can survive throughout the season in the absence of whiteflies. Mixed diets consisting of several species of prey (e.g. different species of aphids) and other non-prey food (e.g. nectar or pollen) are known to favour the development and survival of Chrysoperla rufilabris (Legaspi et al., 1994), Chrysoperla carnea (Patt et al., 2003) and Coccinella septempunctata (Hauge et al., 1998; Nielsen et al., 2002), but the effects of mixed diets consisting of $B$. tabaci and aphids or other alternative food on the demographic parameters of predatory ladybirds have not been evaluated. Therefore, further investigation of the effects of mixed B. tabaci and aphid diets on $S$. japonicum would be valuable in terms of using ladybirds as biological control agents of whiteflies and/or aphids and whether the presence of both prey enhance or reduce the biocontrol of each of them.

ACKNOWLEDGEMENTS. This work was supported by the National Natural Science Foundation of China (No. 31470484) and the National Basic Research Program of the Ministry of Science and Technology, China (973 Programs, 2013CB127600). We greatly appreciate T.J. Ridsdill-Smith and N. Ridsdill-Smith (University of Western Australia, Perth) for linguistic editing and comments. We are grateful for the assistance of all staff members and students in the Key Laboratory of Applied Entomology, Northwest A\&F University at Yangling, Shaanxi, China.

\section{REFERENCES}

Arno J., Gabarra R., Liu T.X., Simmons A.M. \& Gerling D. 2010: Natural enemies of Bemisia tabaci: Predators and parasitoids. In Stansly P.A. \& Naranjo S.E. (eds): Bemisia: Bionomics and Management of a Global Pest. Springer Science+Business Media B.V., pp. 385-421.

Blackman R.L. \& EAStop V.F. 2000: Aphids on the World's Crops: An Identification and Information Guide. John Wiley and Sons, Chichester, $466 \mathrm{pp}$.

Castle S.J., Palumbo J.C., Prabhaker N., Horowitz A.R. \& Denholm I. 2010: Ecological determinants of Bemisia tabaci resistance to insecticides. In Stansly P.A. \& Naranjo S.E. (eds): Bemisia: Bionomics and Management of a Global Pest. Springer Science + Business Media B.V., pp. 423-467.

Dubey A.K., Misra V.S. \& Dixit S.A. 1981: Effect of host plant on the developmental stages of Heliothis armigera. - Indian J. Entomol. 29: 48-57.

Fatiha L., Huang Z., Ren S.X. \& Ali S. 2008: Effect of Verticillium lecanii on biological characteristics and life table of Serangium japonicum (Coleoptera: Coccinellidae), a predator of whiteflies under laboratory conditions. - Insect Sci. 15: 327-333.

Giles K.L., Madden R.D., Stockland R., Payton M.E. \& Dillwith J.W. 2002: Host plants affect predator fitness via the nutritional value of herbivore prey: investigation of a plantaphid-ladybeetle system. - Biocontrol 47: 1-21.

HAMASAKi K. \& MATsui M. 2006: Development and reproduction of an aphidophagous coccinellid, Propylea japonica (Thunberg) (Coleoptera: Coccinellidae), reared on an alternative diet, Ephestia kuehniella Zeller (Lepidoptera: Pyralidae) eggs. Appl. Entomol. Zool. 41: 233-237.

Hauge M.S., Nielsen F.H. \& Toft S. 1998: The influence of three cereal aphid species and mixed diet on larval survival, development and adult weight of Coccinella septempunctata. - Entomol. Exp. Appl. 89: 319-322.

He Y.X., Zhao J.W., Zheng Y., Desneux N. \& Wu K.M. 2012: Lethal effect of imidacloprid on the occinellid predator Serangium japonicum and sublethal effects on predator voracity and on functional response to the whitefly Bemisia tabaci. - Ecotoxicology 21: 1291-1300.

Hodek I. 1996: Food relationships. In Hodek I. \& Honek A. (eds): Ecology of Coccinellidae. Kluwer, Dordrecht, pp. 143-238.

Hu Q.B., An X.C., Jin F.L., Freed S. \& Ren S.X. 2009: Toxicities of destruxins against Bemisia tabaci and its natural enemy, Serangium japonicum. - Toxicon 53: 115-121.

Hu J., De Barro P., Zhao H., Wang J., Nardi F. \& Liu S.S. 2011: An extensive field survey combined with a phylogenetic analysis reveals rapid and widespread invasion of two alien whiteflies in China. - PLoS ONE 6(1): e16061, 9 pp.

Jing Y., Huang J., Ma R.Y. \& Han J.C. 2003: Biological characteristics of Serangium japonicum and its morphology in comparion with Delphastus catalinae. - J. Fujian Agr. For. Univ. 32: $172-175$.

Kim J.S., Kim T.H. \& LeE S.G. 2005: Bionomics of the green peach aphid (Myzus persicae Sülzer) adults on Chinese cabbage (Brassica campestris). - Kor. J. Appl. Entomol. 44: 213-217.

Legaspi J.C., CARruthers R.I. \& Nordlund D.A. 1994: Life history of Chrysoperla rufilabris (Neuroptera, Chrysopidae) provided sweet potato whitefly Bemisia tabaci (Homoptera, Aleyrodidae) and other food. - Biol. Contr. 4: 178-184.

Li P., CHeN Q.Z. \& LiU T.X. 2015: Effects of a juvenile hormone analog, pyriproxyfen, on Serangium japonicum (Coleoptera: Coccinellidae), a predator of Bemisia tabaci (Hemiptera: Aleyrodidae). - Biol. Contr. 86: 7-13.

Li Y., Xu Z.F., SHi L., SHEN G.M. \& He L. 2016: Insecticide resistance monitoring and metabolicmechanism study of the green peach aphid, Myzus persicae (Sulzer) (Hemiptera: Aphididae), in Chongqing, China. - Pesticide Biochem. Physiol. 132: $21-28$.

Lin K.J, Wu K.M., Zhang Y.J. \& Guo Y.Y. 2008: Naturally occurring population of Bemisia tabaci, biotype $\mathrm{B}$ and associated natural enemies in agroecosystem in northern China. - Biocontr. Sci. Technol. 18: 169-182.

Naranjo S.E., Castle S.J., De Barro P.J. \& Liu S.S. 2010: Population dynamics, demography, dispersal and spread of Bemisia tabaci. In Stansly P.A. \& Naranjo S.E. (eds): Bemisia: Bionom$i c s$ and Management of a Global Pest. Springer Science + Business Media B.V., pp. 185-226.

Nielsen F.H., Hauge M.S. \& Toft S. 2002: The influence of mixed aphid diets on larval performance of Coccinella septempunctata (Col., Coccinellidae). - J. Appl. Entomol. 126: 194-197.

Obrycki J.J. \& KRING T.J. 1998: Predaceous coccinellidae in biological control. — Annu. Rev. Entomol. 43: 295-321. 
OMKAR \& SRIVASTAVA S. 2003: Influence of six aphid prey species on development and reproduction of a ladybird beetle, Coccinella septempunctata. - BioControl 48: 379-393.

Osman M.Z. \& Selman B.J. 1993: Suitability of different aphid species to the predator Chrysoperla carnea Stephens (Neuroptera: Chrysopidae). - Univ. J. Zool. (Rajshahi) 12: 101-105.

Patt J.M., Wainright S.C., Hamilton G.C., Whittinghill D., Bosley K., Dietrick J. \& Lashomb J.H. 2003: Assimilation of carbon and nitrogen from pollen and nectar by a predaceous larva and its effects on growth and development. - Ecol. Entomol. 28: 717-728.

Ren S.X, WANG Z.Z, Qiu B.L \& XIAO Y. 2001: The best status of Bemisia tabaci in China and non-chemical control strategies. - Insect Sci. 8: 279-288.

Ren S.X, Wang X.M, Pang H., Peng Z.Q. \& Zeng T. 2009: Colored Pictorial Handbook of Ladybird Beetles in China. Science Press, Beijing, $336 \mathrm{pp}$.

Stansly P.A. \& Natwick E.T. 2010: Integrated systems for managing Bemisia tabaci in protected and open field agriculture. In Stansly P.A. \& Naranjo S.E. (eds): Bemisia: Bionomics and Management of a Global Pest. Springer Science+Business Media B.V., pp. 467-497.

Strohmeyer H.H., Stamp N.E., Jarzomski C.M. \& Bowers M.D. 1998: Prey species and prey diet affect growth of invertebrate predators. - Ecol. Entomol. 16: 68-79.
THOMPSON S.N. 1999: Nutrition and culture of entomophagous insects. - Annu. Rev. Entomol. 44: 561-592.

Wu X.X., Hu D.X., Li Z.X. \& SHEN Z.R. 2002: Using RAPDPCR to distinguish biotypes of Bemisia tabaci (Homoptera: Aleyrodidae) in China. - Entomol. Sin. 9(3): 1-8.

Yao S.L., Huang Z., Ren S.X., Mandour N. \& Ali S. 2011: Effects of temperature on development, survival, longevity, and fecundity of Serangium japonicum (Coleoptera: Coccinellidae), a predator of Bemisia tabaci Gennadius (Homoptera: Aleyrodidae). - Biocontr. Sci. Technol. 21: 23-34.

Yao F.L., Zheng Y., Zhao J.W., Desneux N., He Y.X. \& Weng Q.Y. 2015: Lethal and sublethal effects of thiamethoxam on the whitefly predator Serangium japonicum (Coleoptera: Coccinellidae) through different exposure routes. - Chemosphere 128: $49-55$.

Zhang S.Z., Zhang F. \& Hua B.Z. 2007: Suitability of various prey types for the development of Propylea japonica (Coleoptera: Coccinellidae). - Eur. J. Entomol. 104: 149-152.

Zhang S.Z., Li J.J., Shan H.W., Zhang F. \& Liu T.X. 2012: Influence of five aphid species on development and reproduction of Propylaea japonica (Coleoptera: Coccinellidae). — Biol. Contr. 62: 135-139.

Received July 28, 2017; revised and accepted December 11, 2017 Published online December 28, 2017 